\title{
KULBERT ZSÓFIA: A világörökségek szerepe a nyugat-dunántúli régió turizmusfejlesztésében
}

\begin{abstract}
When we advert the trends of the tourism of the past years, we can see that those produces, which are based on unique experiences, became more popular, than other ones. In the other side, nowadays the experience is beginning to turn into a new category of tourism very forcefully.

In the ground of West-Transdanubien region there are two spot, which are parts of the World-Heritage: The Arch abbey of Pannonhalma, which was getting into to the list in 1996, and the Fertö culture land. It may be hypothesized, that the World Heritage denomination involves a rise in the number of visitors.

The circumstances at the moment are not so rewarding, to fulfil the hopes, what the tourism appends to it; it would be need complex innovate, which includes some important component: to develop the policy of tourism and the efficient management.
\end{abstract}

\section{Bevezetés}

Napjainkban a kulturális igények iránti kereslet egyre inkább fokozódik. A nagyvárosok rohanó hétköznapjaitól elszakadva elötérbe kerülnek a „vidéki” értékek.

Az elmúlt évek turizmustrendjeit figyelembe véve a világon mindenütt az egyediségre építö turisztikai termékek váltak népszerübbé. A maslow-i szükséglet piramisnak megfelelöen az idegenforgalomban is megfigyelhető a magasabb szintű igények kielégítése iránti vágy; az esztétikumra, az önmegvalósításra és a kulturális önazonosságra való törekvés. A WTO ezt a jelenséget úgy fogalmazza meg, hogy folyamatosan áttérés következik be a „,szolgáltatásgazdaság”-ból az úgynevezett „élménygazdaság”-ba. A fogyasztás személyes jellegüvé válik, a kínálat pedig egy új hozzáadott értékkel gazdagodik: az élményekkel. Az egyre inkább személytelenné váló munkából való menekülés fokozatosan arra készteti az embereket, hogy utazzanak és valami újat ismerhessenek meg, valami újban vegyenek részt és mindeközben élményekkel gazdagodjanak.

Jóllehet az élmény szubjektiv és megfoghatatlan kategória, a turizmus ágazatai közül belöle az egyik legtöbbet kínáló az örökségturizmus. Hiszen mi lehet egyedibb, vonzóbb egy adott tájegység történelménél, kultúrájánál? Jelenlegi életünk kommercializálódó kultúrájával szembeni válasznak tűnik tehát a történelmi és kulturális örökségek felértékelỏdése, a hagyományok és gyökerek felé fordulás, amihez persze az is szükséges, hogy az érintettek át és meg tudják élni mindazt, amit az örökségértékek közvetitenek.

\section{Világszerte elismert örökségek}

Az örökségértékek fenntarthatóságának biztosításában a nemzeti, állami szintủ keretek sok esetben kevésnek bizonyultak, így egyre inkább nyilvánvalóvá vált, hogy szükség van egy globális felelősségvállalást lehetővé tevő, nemzeteken átivelő egyezményre. Ezért

\footnotetext{
• PhD-hallgató - Nyugat-magyarországi Egyetem Közgazdaságtudományi Kar.
} 
hozta létre az UNESCO - az ENSZ az emberiség örökségének védelmével és megörzésével foglalkozó szervezete - a Világörökség Egyezményt 1972 novemberében.

Az egyezmény a listára felkerült egyetemes örökségeket három kategóriába sorolja. A kulturális örökségek közé müemlékek, épületek, épületegyüttesek és helyszinek tartoznak; a természeti örökségek között fizikai, biológiai, geológiai képződményeket, veszélyeztetett fajok élettereit és természeti tájakat tartanak nyilván. Mivel szinte már sehol sem találhatunk olyan területeket, amelyek tökéletesen mentesek volnának az emberi hatásoktól, szükség volt egy harmadik kategória felállitására is. Azok a helyszínek, amelyek a kulturális és természeti értékek keverékei, a „vegyes” kategóriába nyernek besorolást.

Világörökségek védelmére vonatkozó egyezményt összesen 878 helyszín esetében írtak alá, melyek megoszlása az egyes kategóriák között nem egyenletes. A helyszínek közül 679 kulturális, 174 pedig természeti kategóriában felelt meg az Egyezmény kritériumainak, 25 helyszín besorolása pedig „vegyes”, vagyis ezek mind a kulturális, mind a természeti örökség feltételeit teljesítik.

\section{A világörökségek és a turizmus kapcsolatrendszere}

A világörökséges különleges helyzetben vannak az örökségattrakciók között, hiszen egyfelöl kiemelt védettséget élveznek, igy rájuk szigorú szabályozás vonatkozik, ugyanakkor kiemelkedő turistavonzó képességgel rendelkeznek. Éppen ezért ezeket a nemzeti turizmusfejlesztési stratégiák is kiemelten kezelik, hiszen turisztikai hasznosításuk csak fokozott védelmük szem elött tartása mellett történhet meg.

Mindezek alapján tehát a felismert örökségértékek egyre nagyobb szerepet kaphatnak az adott térség idegenforgalmának alakításában, ezáltal gazdasági fejlődésében és a regionális fejlesztésben is. Amellett, hogy jelentős növekedést generálhatnak a térségbe érkező turisták számában és növelhetik az eltöltött vendégéjszakák számát, az infrastruktúra fejlesztése és bővítése által aktivan hozzájárulhatnak az adott helyszín területfejlesztéséhez is. A turisztikai infrastruktúra alatt szükebb értelemben az út-, a víz-, a csatorna, az elektromos és a távközlési hálózat összességét kell érteni, tágabb értelemben pedig ide kapcsolódik minden, az örökségértékek megtekintéséhez kapcsolódó szolgáltatás megteremtése szállás, étkezés, kereskedelem - is. Ezek az említett turisztikai fejlesztések jelentős munkahelynövekedést is generálhatnak.

\section{A nyugat-dunántúli régió világörökség cimet elnyert helyszínei}

Hazánk a Világörökség Egyezményhez 1985-ben csatlakozott, 1987 óta összes nyolc világörökség helyszinnek adva otthont, melyek közül hét a kulturális, egy pedig a természeti kategóriába tartozik.

A nyugat-dunántúli régió területén ezek közül kettő található: a listára 1996-ban felkerült Pannonhalmi Bencés Főapátság és a Fertö-tó kultúrtáj. Ez utóbbi érdekessége és egyben óriási lehetőségeket magában hordozó tulajdonsága, hogy felvételét 2001-ben Ausztria és Magyarország közösen kezdeményezte. 


\subsection{A Pannonhalmi Bencés Fõapátság}

A Főapátság a még ma is aktiv keresztény monostorok egyik egyedülálló példája, amelynek szerzetesközössége egész Közép-Európában hozzájárult a kultúra fejlesztéséhez és a kereszténység terjedéséhez. Ezen egyetemes értékeknek köszönhetően 1996-ban alapitásának 1000. évforduloján - érdemelte ki felvételét az UNESCO Világörökségi Listájára.

\subsubsection{Lehetõségek a Fỏapátság turizmusának fejlesztésére}

Az apátság Pannonhalma településtöl elkülönülten, a Szent Márton-hegyen található, önmagában is önálló egységet alkot. Aktiv turisztikai kapcsolata egyik környezö településsel sincs, éppen ezért a világörökségi cím elnyeréséből fakadó helyzeti elönyét sem tudja kihasználni.

A páratlan értékü müemlékegyüttest èvente mintegy százezer látogató keresi fel, azonban a közelben található - a világörökségnek szintén részét képező - Milleniumi Emlékmühöz és a Kálváriához vagy a Boldog Mór kilátóhoz csak töredékük sétál el. A vendégek többsége sem az épülettömb kömyezetében, sem pedig a faluban nem tölt el hosszabb idöt, hiszen a meglévö adottságok ismeretlenek és a bennük rejlö lehetőségek jórészt még kihasználatlanok.

A látogatottság hatékonyabb kihasználásához és az idegenforgalmi bevételek növeléséhez elsősorban a látogatók tartózkodási idejét kell növelni. Mivel az épületegyüttesben a tanév idötartama alatt mintegy ötszáz ember éli mindennapjait, befogadóképessége korlátozott. Ennek figyelembevételével a tartózkodási idő növelésének eszközeit az épületegyüttes falain kivül kell megteremteni. Erre számtalan lehetöség kínálkozik, hiszen a kulturális turizmus a turizmus más ágaival is jól kombinálható.

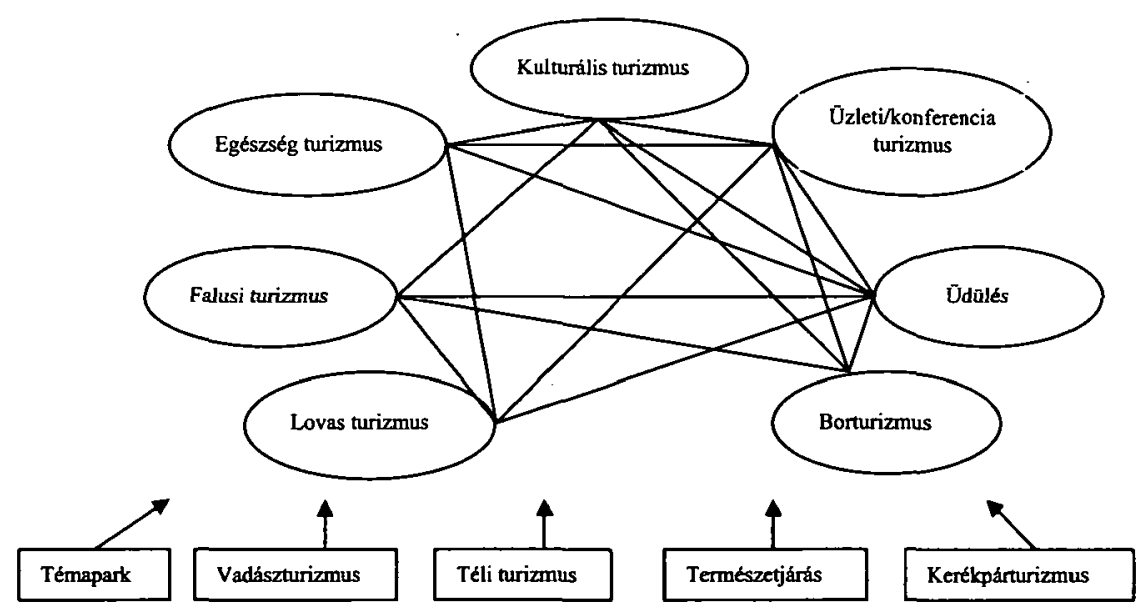

1. ábra. A turisztikai termékfejlesztés lehetséges kombinácioja (Forrás: Piskóti-Dankó-Schupler 2002, 231. p.)

Új kinálati elemek bevezetésével és a környező falvak lelkes vállalkozóinak bekapcsolásával a Főapátság és kőrnyezete új, ōsszetett turisztikai termékkínálat biztosítására lesz képes. Egyik lehetséges kapcsolódási pontként a Föapátságban termelt füszernövények és 
bor mellett további helyi termékek turisztikai kínálatba történő bevonását látom. Jól kidolgozott, tervszerü marketingtevékenység kialakításával a látogatók száma jelentősen növelhető és a turisztikai termékekre jellemző szezonalitás is csökkenthető. Mindez természetesen csak a környező településekkel való szorosabb együttmüködés eredményeként jöhet létre, ugyanakkor kölcsönös előnyöket is eredményez, hiszen a Föapátság és a bekapcsolódó önkormányzatok és vállalkozók is profitálhatnak a turisztikai forgalomból.

\subsection{Fertő-tó/Neusiedlersee kultúrtáj}

A Fertő-tavat az UNESCO 1979-ben egyedi természeti értékei miatt bioszféra rezervátummá nyilvánította, majd a tavat övező településekkel együtt 2001-ben, mint kultúrtájat vette fel a Világörökségi Listára.

A területhez magyar oldalról a Fertö-Hanság Nemzeti Park Fertő-tavi részének teljes területe, valamint Fertőboz, Fertőrákos településközpont műemléki jelentőségủ része és kőfejtöje, a fertődi Esterházy-, a nagycenki Széchenyi-kastély és környezetük tartozik (a pufferzónához tartozó települések: Balf, Nagycenk, Hidegség, Fertöhomok, Hegykő, Fertőszéplak, Sarród, Fertöújlak). Az osztrák fél a NeusiedlerseeSeewinkel Nationalpark vizes élöhelyeinek területét és a müemléki védelem alatt álló Rust szabad város belvárosát terjesztette fel.

\subsubsection{Lehetőségek a Fertő-táj, mint világörökség turisztikai fejlesztésére}

A kultúrtáj területét tekintve többszöröse az Apátság védett területének, nemcsak a tó és közvetlen környezete, hanem az azt övező települések és épített örökségeik is részét képezik, éppen ezért a marketingtevékenységben kiemelt szerepet kell kapnia az egységes arculat kialakításának, amelynek a térség összetartozását is nyilvánvalóvá kell tennie.

A nemzeti park cím - jóllehet csak 7 évvel korábbi - a köztudatba sokkal jobban beépült, mint a világörökségi, véleményem szerint sem a turisztikai termékek kialakításában, sem pedig a térségi marketingben nem használják

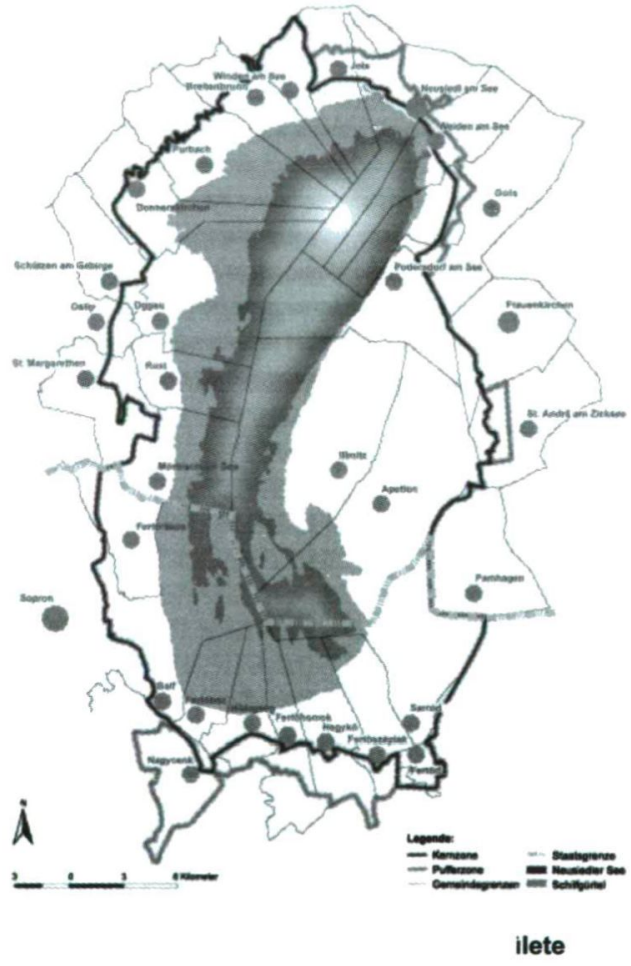
ki az e cím nyújtotta elönyöket és lehetőségeket.

A következő két grafikon a fertődi Esterházy-kastély, illetve a nagycenki Széchenyikastély látogatói számának alakulását mutatja. Az elöbbi esetében 2003 és 2008 között, az utóbbinál pedig 1995és 2008 között. 

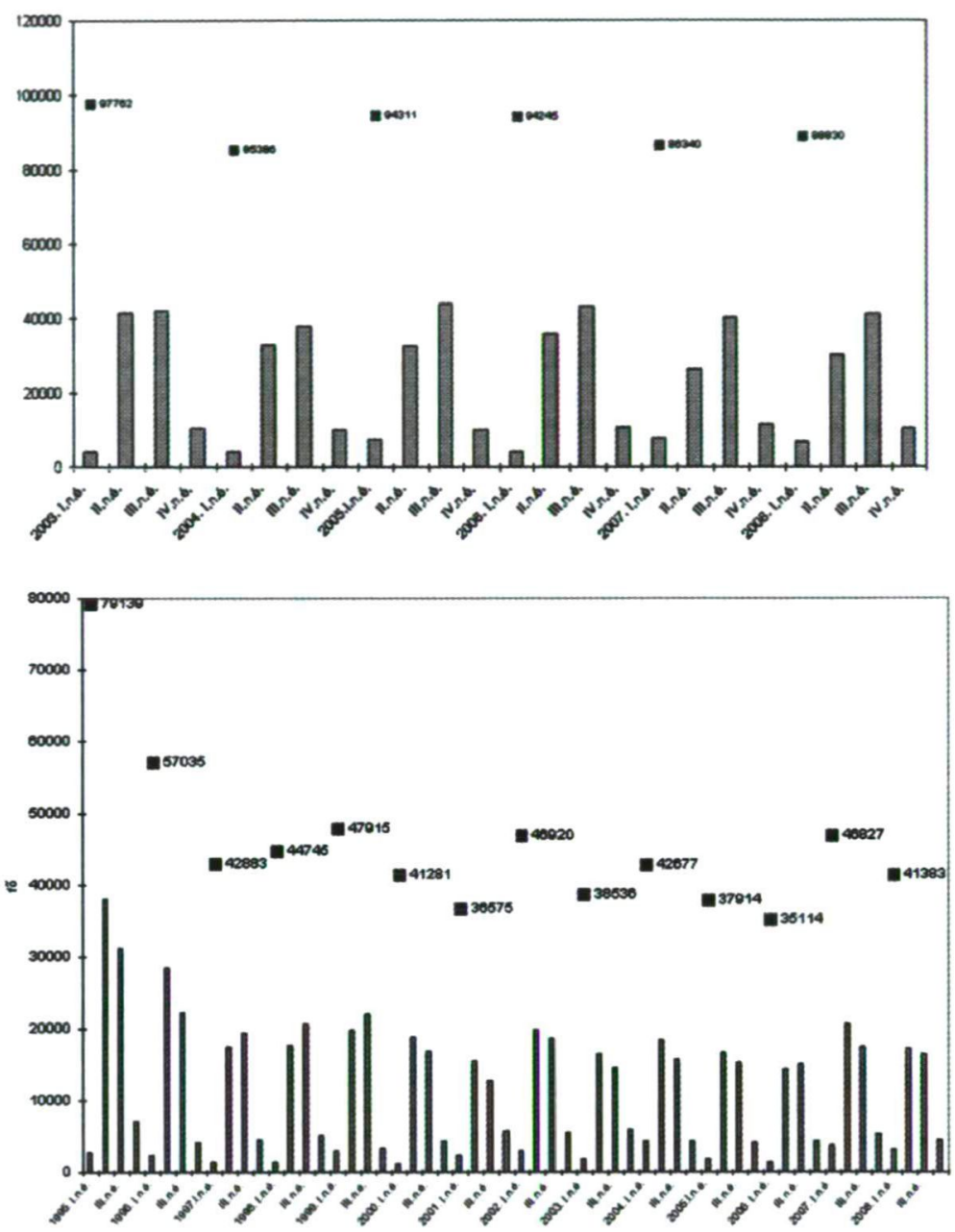

3-4. ábra. A fertődi Esterházy-és a nagycenki Széchenyi-kastély látogatói számának alakulása (Forrás: Esterházy-kastély, Fertőd, ill. Győr-Moson-Sopron megyei Múzeumok Igazgatósága, Széchényi István Emlékmúzeum, Nagycenk)

Az adatokból élesen látszik a tavaszi, illetve nyári negyedév döntő szerepe az éves látogatószám alakulásából, vagyis az, hogy szezonális turisztikai terméknek tekinthető mindkét múzeum. A második grafikon adatsora pedig azt is megmutatja, hogy a látogatók száma évröl évre hasonló szinten alakul, a világörökséggé nyilvánítás elött és után egyaránt.

A térségben egyedül a Fertőrákoson müködő kőfejtő statisztikai adataiból látszik az, hogy 2001-től, a világörökséggé nyilvánitástól megemelkedett a látogatók száma. Tavaszi és nyári időszakban közel kétszeresére nőtt a kőfejtőt felkeresők száma. Mindez a hatékonyabb marketingtevékenységgel, illetve egy nagyobb beruházás során történt fejlesztéssel magyarázható. 


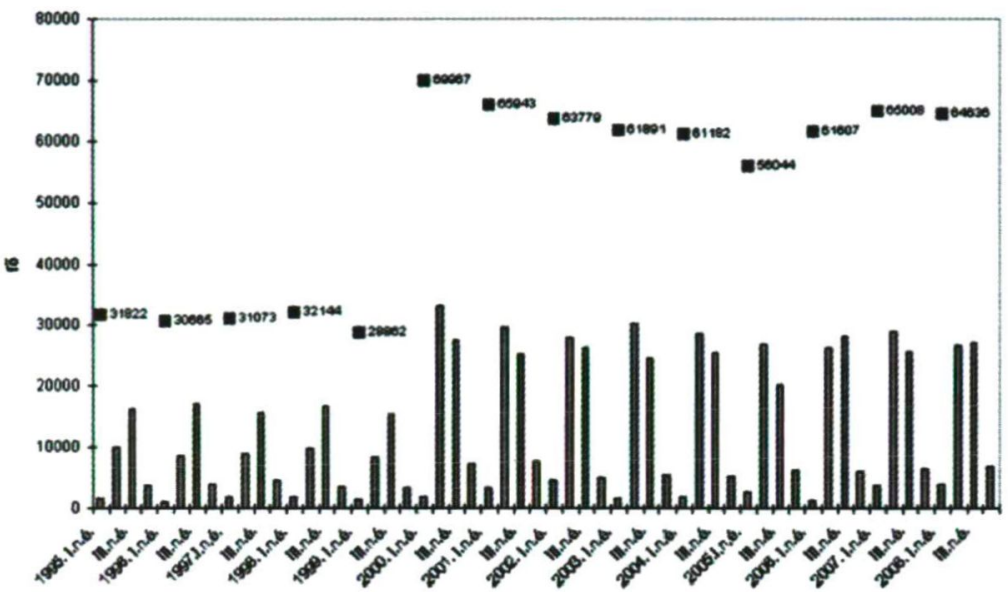

5. ábra. A fertőrákosi kőfejtő látogatói számának alakulása (1995-2008) (Forrás: Fertőrákosi kőfejtő)

Azonban úgy gondolom, hogy a térség adottságai kedvezőnek tekinthetők, és úgy gondolom, hogy egy megfelelő, határon átnyúló és több szinten megvalósuló turisztikai összefogással nagyobb lehetőség nyílna egyedi vonzerők kialakítására és ezáltal hatékony turizmus realizálására.

A hatékony turizmus müködését az alábbi modell szerint képzelem el:

\section{A Fertő-táj turizmusának elemei}

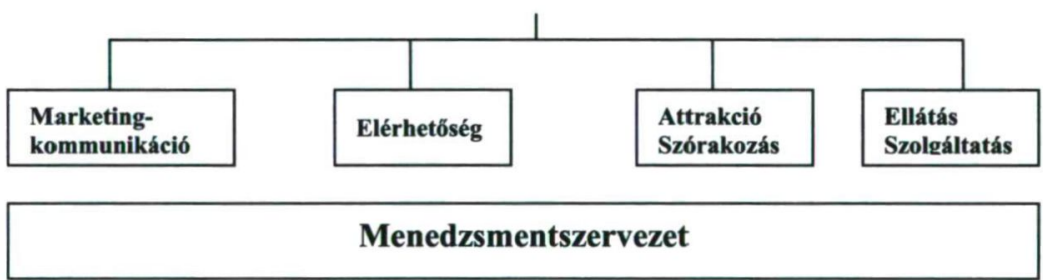

6. ábra. A Fertō-táj turizmusának meghatározó elemei

(Forrás: saját szerkesztés)

A hatékony turizmus egyik legfontosabb eleme a teljes területet átfogó marketingkommunikáció. A turisztikai termékekre jellemző megfoghatatlanság a Fertö-táj esetében különösen igaz. Éppen ezért a marketingnek elsődleges feladata a megfoghatóvá tétel, amihez mindent átható, imázst adó arculat segítségével eladható tartalommal kell feltölteni a világörökség fogalmát.

$\mathrm{Az}$ arculat kialakításának elemei részben már adottak, hiszen létezik a világon mindenütt ismert és használt logó, azonban jelenlegi felhasználási köre korántsem teljes körü.

Természetesen azt is szem elött kell tartani, hogy a kulturális értékhez egyéni szolgáltatók is kapcsolódnak, akik egyénileg saját arculattal lépnek piacra, ugyanakkor a világörökség esetében a többi szolgáltatóval együttesen, egységesen kellene megjelenniük.

Ha a térség kulturális értékeit széles körben ismertté szeretnénk tenni, akkor elsősorban 
a helyieket kell megnyernünk. Ennek oka egyrészröl az, hogy a helyi attrakció számukra is kikapcsolódási és költési lehetöséget biztosíthat, másrészröl pedig, ha velük sikerül megismertetni a terület jelentőségét, akkor a büszke helybeliek pozitiv képet közvetítenek a velük kapcsolatba kerülö turistáknak.

A népszerüsités elemeként célszerü megjelentetni olyan exkluziv kiadványokat, amelyek célja csupán a figyelemfelkeltés, illetve olyan részletes programkatalógusokat is, amelyek a térség részletes bemutatására, a programlehetöségek és az igénybe vehetö szolgáltatások, továbbá ezek árainak ismertetésẻre törekszenek.

Elérhetőség alatt részben a fizikai, részben pedig a piaci megközelitést értem. A Fertötáj kulturális világörökség különbözö épített és természeti vonzeröi egymástól területileg elkülönülten helyezkednek el, így alapvető feladat a vonzerök összekötése, tehát mindaz az épitett és természeti környezet, amelyen a látogatóknak keresztül kell haladnia, kikerülhetetlen részét képezik az élményeknek. A turisták szempontjából ennek az információs rendszernek elengedhetetlen elemei az információs táblák.

A térség fejlesztésével párhuzamosan a vendégforgalomnak és a vendégösszetételnek megfelelöen fejleszteni kell a kapcsolódó szolgáltatások színvonalát is.

Szálláshelyek tekintetében a területen elsösorban a falusi turizmus szálláshelyeire lehet alapozni, ugyanakkor ezeken kivül Sopronban minösitett szálláshelyek ajánlására is lehetőség nyilik.

A szolgáltatások között fontosnak tartom megemlíteni az osztrák oldalon már 10 éve forgalomban lévő Fertő-tó kártyát, melyet az elmúlt évben több, mint 175 ezer vendég igényelt, és amellyel 38 ingyen szolgáltatást lehet igénybe venni Észak-Burgenland különböző turisztikai intézményeiben. A kártya magyar oldalon történő bevezetésére évek óta szükség lenne, mint ahogyan egy közös többnyelvü honlap müködtetésére is. A honlap elönye, hogy a rajta tárolt információk bárhonnan elérhetőek, és bármikor frissíthetőek lennének, illetve egy helyen megtalálhatóvá válna a térség teljes programkínálata.

A különböző szolgáltatások összefogására célszerü önálló menedzsment szervezetet létrehozni. Ennek a szervezetnek a feladata a szolgáltatókkal történő folyamatos együttmüködés, a különféle marketingfeladatok ellátása, a piackutatások végzése, a szükséges állami és önkormányzati pénzforrások beszerzése, a magánvállalkozások hozzájárulásainak kezelése, továbbá a közös érdekképviselet ellátása, illetve más turizmus marketing szervezetekkel történő együttmüködés kialakítása.

\section{5. Összefoglalás}

Mindkét világörökség helyszín páratlan és egyedülálló szinfoltja a nyugat-dunántúli régiónak. Feltételezhetö lenne, hogy a világörökség címük önmagában is a látogatók számának növekedését vonja maga után. Jelen körülmények között azonban egyik nyugat-dunántúli világörökségi emlék sem alkalmas arra, hogy beváltsa a turizmus által hozzá füzött reményeket; ehhez mindenképpen komplex fejlesztésre lenne szükség, melynek nélkülözhetetlen elmei a közös turisztikai politika kialakítása és a hatékony menedzsment.

\section{Irodalomjegyzék}

Lengyel Márton (2004): A turizmus általános elmélete, KIT Kft. Budapest.

Piskóti István-Dankó László-Schupler Helmut (2002): Régió- és településmarketing, KJK Kerszöv. Budapest.

Puczkó László-Rátz Tamara (1998): A turizmus hatásai. Aula Kiadó, Budapest. 177. p.

http://whc.unesco.org/en/list

http://www.neusiedler-see.at 